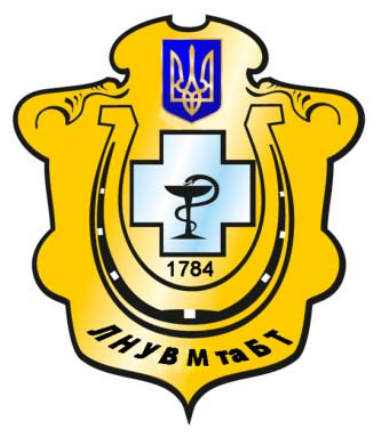

Науковий вісник Львівського національного університету ветеринарної медицини та біотехнологій імені С.3. Гжицького

Scientific Messenger of Lviv National University of Veterinary Medicine and Biotechnologies named after S.Z. Gzhytskyj

doi:10.15421/nvlvet7744

ISSN 2518-7554 print

ISSN 2518-1327 online

$\underline{\text { http://nvlvet.com.ua/ }}$

УДК 619: 618. 11-(075.8)

\title{
Влив препарату «Фос-Бевіт» на вміст холестеролу та концентрацію сечової кислоти в організмі корів та перебіг у них післяотельного періоду
}

\author{
І.Б. Кобилюх ${ }^{1}$, Я.С. Стравський ${ }^{1}$, В.Ю. Стефаник ${ }^{2}$, С.С. Костишин ${ }^{2}$ \\ terdosvet@meta.ua \\ ${ }^{1}$ Тернопільська дослідна станиія Інституту ветеринарної медицини НААН Украӥни \\ вул. Тролейбусна, 12, м. Тернопіль, 46027, Україна; \\ ${ }^{2}$ Львівський національний університет ветеринарної медицини та біотехнологій імені С.3. Гюсицького, \\ вул. Пекарська, 50, м. Львів, 79010, Україна
}

\begin{abstract}
Тендениія поширення післяродових ускладнень молочного стада в сучасних умовах диктує необхідність використання нових засобів та схем профілактики акушерської патології у корів. Метою дослідження було вивчити влив препарату «Фос-Бевіт» на вміст холестеролу та конщентрацію сечової кислоти в організмі корів і перебіг у них післяотельного періоду. Дослід проведено у ТзОВ «Агропродсервіс-Інвест» Козівського району Тернопільської області на коровах украӥнськоі чорно-рябої молочної породи. Для розробки схеми застосування препарату з імуностимулюючими властивостями нами використано «Фос-Бевіт» - комплексний препарат виробництва ТзОВ НВФ «Бровафарма» на основі бутафосфану і трьох вітамінів групи В (нікотинаміду, фолієвої кислоти, иіанокобаламіну), який застосовують великій рогатій худобі при порушенні обміну речовин, вітамінній недостатності, як стимулюючий і тонізуючий засіб для підвищення опірності організму до захворювань різної етіології, поліпшення росту та розвитку.

Після застосування препарату «Фос-Бевіт» внутрішньом'язово по 0,3 мл на 10 кг маси тіла на 1, 5 добу після отелення у крові корів зростає вміст холестеролу на $10,69 \%(P \leq 0,05)$ і зменшується на $14,27 \%(P \leq 0,05)$ конщентрація сечовоі кислоти, що свідчить про посилення в їх організмі обміну речовин та активацію антиоксидантної системи. Препарат «Фос-Бевіт» позитивно виливав на перебіг післяродового періоду корів, про щзо свідчить скорочення тривалості сервісперіоду на 75 діб $(P \leq 0,01)$ та зменшення індексу осіменіння на 0,4 одиниці, порівняно з відповідними показниками корів контрольної групи, у яких діагностовано субклінічний ендометрит та субклінічний мастит. Препарат «Фос-Бевіт» можна рекомендувати для включення у технологічну схему профілактики післяродових ускладнень у корів.

Ключові слова: «Фос-Бевіт», післяродова патологія, холестерол, сечова кислота, сервіс-період.
\end{abstract}

\section{Влияние препарата «Фос-Бевит» на содержание холестерола и концентра- цию мочевой кислоты в организме коров и течение послеродового периода}

\author{
И.Б. Кобылюх ${ }^{1}$, Я.С. Стравский ${ }^{1}$, В.Ю. Стефанык ${ }^{2}$, Е.Е. Костышин ${ }^{2}$ \\ terdosvet@meta.ua \\ ${ }^{1}$ Тернопольская опытная станщия Института ветеринарной медицины НАAН, \\ ул. Троллейбусная, 12, г. Тернополь, 46027, Украина; \\ ${ }^{2}$ Львовский национальный университет ветеринарной медицины и биотехнологий имени С.З. Гжицкого, \\ ул. Пекарская, 50, г. Львов, 79010, Украина
}

Тенденция распространения послеродовых осложнений молочного стада в современных условиях диктует необходимость использования новых средств и схем профилактики акушерской патологии у коров. Целью исследования было изу-

\section{Citation:}

Kobylyukh, I.B., Stravskiy, Y.S., Stefanyk, V.Y., Kostyshyn, Y.Y. (2017). The influence of the preparation «Fos-Bevit» on the content of cholesterol and the concentration of urine acid in cows' organism and the processes in their organism after natal period. Scientific Messenger LNUVMBT named after S.Z. Gzhytskyj, 19(77), 204-207. 
чить влияние препарата «Фос-Бевит» на содержание холестерина и кониентрачию мочевой кислоть в организме коров и ход у них послеродового периода. Опыт проведения в ООО «Агропродсервис-Инвест» Козовского района Тернопольской области на коровах украинской черно-рябой молочной породы. Для разработки схемы применения препарата с иммуностимулируюшими свойствами нами использован «Фос-Бевит» - комплексный препарат производства ООО НПФ «Бровафарма» на основе Бутафосфан и трех витаминов группь В (никотинамида, фолиевой кислотыл, ичианкобаламина), который применяют крупному рогатому скоту при нарушении обмена веществ, витаминной недостаточности, как стимулирующее и тонизирующее средство для повышения сопротивляемости организма к заболеваниям различной этиологии, улучшения роста и развития.

После применения препарата «Фос-Бевит» внутримышечно в дозе 0,3 мл на 10 кг массы тела на 1, 5 сутки после отела в крови коров увеличивается содержание холестерола на 10,69\% $(P \leq 0,05)$ и снижается на 14,27\% (P $\leq 0,05)$ концентрация мочевой кислоты, что способствует активачии антиоксидантной системы организма и обмена веществ. Препарат «ФосБевит» положительно влияет на послеродовый период, о чем свидетельствует сокращение сервис-периода на 75 суток $(P \leq 0,01)$ и снижение индекса осеменения на 0,4 единицы в сравнении с коровами контрольной группь, у которых диагностировали субклинический эндометрит и мастит. Препарат «Фос-Бевит» рекомендуется для включения в технологическую схему профилактики послеродовых заболеваний у коров.

Ключевые слова: «Фос-Бевит», послеродовая патология, холестерол, мочевая кислота, сервис-период.

\title{
The influence of the preparation «Fos-Bevit» on the content of cholesterol and the concentration of urine acid in cows' organism and the processes in their organism after natal period
}

\author{
I.B. Kobylyukh ${ }^{1}$, Y.S. Stravskiy ${ }^{1}$, V.Y. Stefanyk ${ }^{2}$, Y.Y. Kostyshyn ${ }^{2}$ \\ terdosvet@meta.ua \\ ${ }^{I}$ Ternopil research station of the Institute of veterinary medicine NAAS, \\ Trolley Str., 12, Ternopil, 46027, Ukraine; \\ ${ }^{2}$ Lviv national university of veterinary medicine and biotechnologies named after S. Gzhytskyj, \\ Pekarska Str., 50, Lviv, 79010, Ukraine
}

\begin{abstract}
The tendency of spreading postnatal complications of dairy herd in modern conditions requires the use of new tools and prevention schemes obstetric pathology in cows. The aim of the study was to explore the impact of the preparation "Fos-Bevit» on cholesterol content and the concentration of uric acid in the organism of cows and the course of their postnatal period. The experiment conducted in LLC «Agroprodservice-Invest» of Kozivskyi district, Ternopil region on cows of Ukrainian black and white dairy cattle breed. In order to design the scheme of the preparation usage with immunostimulating properties we used «Fos-Bevit»-a complex preparation of production of LLC SPC «Brovafarma» based on butafosfan and three group B vitamins (nicotinamide, folic acid, cyanocobalamin), which apply to cattle metabolic disorders, vitamin deficiency, as a stimulant and a tonic preparation to boost the body's resistance to diseases of various etiologies, improving the growth and development. Having used the preparation «Fos-Bevit» intramuscular in dose of $0,3 \mathrm{ml} / 10 \mathrm{~kg}$ of body mass for 1.5 day after calving in the blood of cows increases the cholesterol content by $10.69 \%(P \leq 0.05)$ and decreases by $14.27 \%(P \leq 0.05)$ the concentration of uric acid, which contributes to the activation of the body's antioxidant system and metabolism. The preparation «Fos-Bevit» positively influence the after born period that can be observed the decrease of service period by 75 days $(P \leq 0,01)$ and decrease of the index of insemination for 0.4 item in comparison with cows of the control group in which subclinical endometritis and mastitis were diagnosed. The preparation «Fos-Bevit» is recommended for including into the technological scheme of prophylaxis of afterbirth diseases in cows.
\end{abstract}

Key words: «Fos-Bevit», postpartum pathology, cholesterol, uric acid, service period

\section{Вступ}

Тенденція поширення післяродових ускладнень молочного стада в сучасних умовах диктує необхідність використання нових засобів та схем профілактики акушерської патології у корів.

Хвороби органів відтворення у сільськогосподарських тварин нині розглядають не як локальні захворювання статевих органів, а як загальне захворювання. Враховуючи знижену імунореактивність організму корів при гінекологічних хворобах, доцільним $є$ застосування імуностимуляторів (Degtjarev et al., 2006). 3 вітамінних препаратів запропоновано вводити тривіт, тетравіт, вітаміни А і E (Misajlov et al., 2005). Інші автори одержали позитивний ефект від застосування телицям полівітамінів з гормональними препаратами для стимуляції статевої охоти (Parashchenko, 2001). Ефективним $\epsilon$ використання мінеральних добавок при гіпоплазії яєчників телиць, а саме: селеніт Натрію, ацетат Кобальту, сульфат Магнію, сульфат Цинку, сульфат Марганцю, хлорид Літію, Калію йодиду (Panchyshyn, 2000).

Для лікування і профілактики гінекологічних та післяродових ускладнень у корів використовують препарат «Утеротон» (Sidorkin, 2013).

Серед засобів профілактики і лікування акушерсько-гінекологічних захворювань у корів розроблено цілий ряд внутрішньоматкових антимікробних препаратів. Так застосування «Гінобіотіка» та «Утракуру» у складі комплексної схеми профілактики післяродової патології дозволяє скоротити тривалість неплідності на 12,2-19,9 діб, знизити індекс осіменіння на 0,2-0,3 і домогтися збільшення тільності від першого осіменіння на 23,3-11,5\% (Lozova et al., 2013).

Йодовмісні препарати (йодосол, йодоксид, йодинол), комплексні (спумосан, емульсія НДЛ-1, лефу- 
ран) та піноутворюючі засоби (метромакс, екзутер, Антисепт-Апі) володіють терапевтичною ефективністю від 88,0 до 91,0\% (Tykhonov et al., 2008).

Встановлено, що згодовування хелатних форм Селену та Йоду в поєднанні з сульфатом Кобальту та хлоридом Хрому у кількості 0,2 мг/кг сухої речовини раціону сприяє підвищенню у крові корів вмісту вітамінів А та Е, фенолів, зв'язаних 3 глюкуроновою i сірчаною кислотою, та Кальцію, а в молоці - вітамінів A i E (Khomyn et al., 2007).

Додавання до раціону корів препарату «СелПлекс» супроводжувалося поліпшенням показників їх відтворювальної здатності: скороченням тривалості сервіс-періоду на 13,6\% та зменшенням індексу осіменіння на 14,5\% 3 підвищенням добових надоїв від 7,0 до 15,6\% (Fedoruk et al., 2006).

Застосування коровам препарату «Лігфол» сприяє нормалізації гормонально-метаболічного гомеостазу їх організму та забезпечує оптимальні умови для перебігу родового акту і післяпологових інволюційних процесів (Zolotarev et al., 2010).

Mета $і$ завдання досліджень. Виходячи із вищенаведеного, завданням дослідження було вивчити влив препарату «Фос-Бевіт» на вміст холестеролу та концентрацію сечової кислоти в організмі корів та перебіг у них післяотельного періоду.

\section{Матеріал і методи досліджень}

Дослід проведено у ТзОВ «АгропродсервісІнвест» Козівського району Тернопільської області на коровах української чорно-рябої молочної породи. Лабораторні дослідження проведені в лабораторії ветеринарного акушерства та гінекології Тернопільської дослідної станції ІВМ НААН (свідоцтво про атестацію № РХ-1212/12 від 12.11.2012 року).

У часі сформовано дослідну $(\mathrm{n}=10)$ і контрольну $(\mathrm{n}=10)$ групи тварин. Корови у групи відібрано відповідно до технології рандомізації - призначення піддослідних тварин у групи методом випадкової вибірки, що дозволяє звести до мінімуму статистичні помилки.
Для розробки схеми застосування препарату з імуностимулюючими властивостями нами використано «Фос-Бевіт» - комплексний препарат виробництва ТзОВ НВФ «Бровафарма» на основі бутафосфану i трьох вітамінів групи В (нікотинаміду, фолієвої кислоти, ціанокобаламіну), який застосовують великій рогатій худобі при порушенні обміну речовин, вітамінній недостатності, як стимулюючий і тонізуючий засіб для підвищення опірності організму до захворювань різної етіології, поліпшення росту та розвитку. Препарат вводили внутрішньом'язово по 0,3 мл на 10 кг маси тіла на $y$ 1-5 добу після отелення.

На початку і після завершення досліджуваного періоду в корів контрольних і дослідних груп відібрано кров для біохімічних досліджень.

Вміст загального холестеролувизначали ферментативно, а концентрацію сечової кислоти вимірювали фотометрично при довжині хвилі 590-700 нм (Kondrahin et al., 2004).

Контроль за перебігом післяотельного періоду проведено відповідно до методики акушерської та гінекологічної диспансеризації корів і телиць (Zvereva et al., 1989).

Статистичну обробку результатів проведено з використанням стандартних комп'ютерних програм 3 визначенням середньої арифметичної (M), статистичної похибки середньої арифметичної (m), вірогідності різниці (p) між середніми арифметичними двох варіаційних рядів за довірчим коефіцієнтом для різниці середніх (t) (Vlizlo et al., 2012). Різницю між двома величинами вважали вірогідною за * $-\mathrm{P} \leq 0,05$; ** $\mathrm{P} \leq 0,01 ; * * *-\mathrm{P} \leq 0,001$ (Lakin, 1990).

\section{Результати та їх обговорення}

3 даних, наведених у табл. 1, видно, що після застосування препарату «Фос-Бевіт» у крові корів спостерігалась тенденція до зростання вмісту холестеролу на $10,69 \%(\mathrm{P} \leq 0,05)$ порівняно з початком досліду, що може свідчити про посилення у них обміну речовин, а також збільшення залозистої тканини молочної залози на початку лактаційного періоду.

Таблиия 1

Вміст холестеролу та сечової кислоти в крові корів у післяотельний період після застосування препарату «Фос-Бевіт», $(\mathbf{M} \pm \mathbf{m}, \mathbf{n}=\mathbf{1 0})$

\begin{tabular}{|c|c|c|c|c|}
\hline \multirow{3}{*}{ Показники } & \multicolumn{4}{|c|}{ Групи корів } \\
\hline & \multicolumn{2}{|c|}{ «Фос-Бевіт» } & \multicolumn{2}{|c|}{ контроль } \\
\hline & $\begin{array}{l}\text { початок } \\
\text { досліду }\end{array}$ & $\begin{array}{c}\text { кінець } \\
\text { досліду }\end{array}$ & $\begin{array}{l}\text { початок } \\
\text { досліду }\end{array}$ & кінець досліду \\
\hline Холестерол, ммоль/л & $4,58 \pm 0,13$ & $5,17 \pm 0,15^{*}$ & $4,52 \pm 0,42$ & $4,59 \pm 0,53$ \\
\hline Сечова кислота, мкмоль/л & $68,73 \pm 2,89$ & $58,92 \pm 2,28^{*}$ & $68,34 \pm 3,47$ & $66,71 \pm 2,14$ \\
\hline
\end{tabular}

Примітка: *-P $\leq 0,05$ порівняно з початком досліду

Концентрація сечової кислоти у їх крові зменшилася на $14,27 \%$ (P $\leq 0,05)$, у порівнянні $з$ початком дослідного періоду, що свідчить про активацію антиоксидантної системи організму тварин. Тимчасом як у сироватці крові корів контрольної групи вміст зазначеного показника протягом зазначеного періоду зменшився несуттєво.

Отримані результати досліджень свідчать, що препарат «Фос-Бевіт» в рекомендованих дозах стимулює ліпідний обмін речовин та антиоксидантну систему організму корів у післяотельний період.

3 даних, наведених у табл. 2, видно, що застосування препарату «Фос-Бевіт» в рекомендованій дозі сприяло скороченню тривалості сервіс-періоду на 75 діб (P $\leq 0,01)$ та зменшенню індексу осіменіння на 0,4 одиниці, порівняно з відповідними показниками корів контрольної групи, у яких діагностовано субклінічний ендометрит та субклінічний мастит. 
Відтворна функція корів після застосування препарату «Фос-Бевіт», $(\mathrm{M} \pm \mathbf{m}, \mathbf{n}=10)$

\begin{tabular}{|l|c|c|c|c|}
\hline Групи корів & $\begin{array}{c}\text { Патологія післяродо- } \\
\text { вого періоду }\end{array}$ & $\begin{array}{c}\text { Захворювання корів } \\
\text { на мастит }\end{array}$ & Сервіс-період, діб & Індекс осіменіння \\
\hline «Фос-Бевіт» & $«-»$ & «-» & $44,0 \pm 2,0 * *$ & 1,7 \\
\hline \multicolumn{2}{|c|}{ Контрольна } & 1 & $1 \ll++»$ & $119,0 \pm 8,0$ \\
\hline
\end{tabular}

Отже варто зазначити, що застосування коровам у післяродовий період препарату «Фос-Бевіт» профілактує розвиток патології післяотельного періоду та сприяє швидшому відновленню відтворної функції.

Таким чином, препарат «Фос-Бевіт» можна рекомендувати для включення у технологічну схему 3 профілактики післяродових ускладнень.

\section{Висновки}

Застосування коровам у післяродовий період препарату «Фос-Бевіт» сприяє активації обміну речовин у корів на початку лактаційного періоду, активації антиоксидантної системи їх організму та профілактує розвиток післяотельної патології, що позитивно впливає на відновлення відтворної функції.

Перспектива подальших досліджень полягає у вивченні стану антиоксидатної системи організму корів за застосування препарату «Фос-Бевіт».

\section{Бібліографічні посилання}

Degtjarev, V.P., Leonov, K.V., Guljanskij, A.K. (2006). Korrekcija reproduktivnoj funkcii $\mathrm{u}$ korov pri razlichnyh sosojanijah estestvennoj rezistentosti. Doklady Rossijskoj akademii sel'skohozjajstvennyh nauk. 3, 55-57 (in Russian).

Misajlov, V.D., Nezhdanov, A.G., Mihaljov, V.I. (2005). Metodicheskie rekomendacii po diagnostike, terapii i profilaktike subinvoljucii matki u korov. Voronezh (in Russian).

Parashchenko, I.V. (2001). Synkhronizatsiia vidtvornoi funktsii u telyts. Visnyk Sumskoho DAU. 6, 93-95 (in Ukrainian).

Panchyshyn, V.H. (2000). Aktyvnist funktsionalnykh i morfolohichnykh protsesiv $u$ reproduktyvnykh orhanakh telyts pry zastosuvanni honadotropiniv $\mathrm{z}$ vitaminamy hrupy $\mathrm{V}$ ta mikroelementamy: avtoref. dys. kand. s.-h. nauk: 03.00.13. LDAVM. Lviv, 20 (in Ukrainian).

Sidorkin, V.A. (2013). Opyt i perspektivy primenenija $\beta$ adrenoblokatora «Uteroton» v praktike veterinarnoj mediciny Rossii. Veterinarija. 9, 50-54 (in Russian).
Lozova, L.V., Borodynia, V.I., Fedorov, T.V. (2013). Efektyvnist preparativ hinobiotyk ta utrakur $\mathrm{u}$ profilaktytsi pisliarodovoi patolohii koriv. Veterynarna medytsyna. 97, 450-452 (in Ukrainian).

Tykhonov, O.I., Kovalova, O.O., Silaieva, L.F. (2008). Vyvchennia antybakterialnoi aktyvnosti pinoutvoriuiuchykh palychok «Antysept-Api» dlia likuvannia endometrytiv u veterynarii. Zaporozh. med. zhurn. 5, 68-70 (in Ukrainian).

Khomyn, M.M., Fedoruk, R.S., Oleksiuk, N.P., Khrabko, M.I. (2007). Vmist vitaminiv A i E v krovi ta molotsi i dezintoksykatsiina zdatnist orhanizmu vysokoproduktyvnykh koriv za umov zghodovuvannia khelatnykh form selenu i yodu ta mineralnykh solei kobaltu i khromu. Biolohiia tvaryn. 9(1/2), 170-175 (in Ukrainian).

Fedoruk, R.S., Koleshchuk, O.I., Rivis, Y.F., Tsap, O.F. (2006). Zhyrnokyslotnyi sklad krovi i moloka koriv ta yikh reproduktyvna zdatnist pry zastosuvanni preparatu «Sel-Pleks». Naukovyi visnyk LNAVM im. S. Z. Hzhytskoho. 8, 2(29), 165-169 (in Ukrainian).

Zolotarev, A.I., Ermolova, T.G., Sashnina, L.Ju. (2010). Primenenie Ligfola dlja profilaktiki omfalo- flebita $u$ teljat. «Nauchnoe obespechenie agropromyshlennogo proizvodstva», mezhdunarodnaja nauchnoprakticheskaja konferencija. Kursk, 107-109 (in Russian).

Kondrahin, I.P., Arhipov, A.V., Levchenko, V.I. (2004). Metody veterinarnoj klinicheskoj laboratornoj diagnostiki. M.: KolosS (in Russian).

Zvereva, G.V., Homin, S.P., Oleskiv, V.N. (1989). Metodika akusherskoj i ginekologicheskoj dispanserizacii korov i telok. L'vov: L'vovskij zooveterinarnyj in-t (in Russian).

Vlizlo, V.V., Fedoruk, R.S., Ratych, I.B. (2012). Laboratorni metody doslidzhen $u$ biolohii, tvarynnytstvi ta veterynarnii medytsyni [Tekst]: dovidnyk. Lviv: SPOLOM (in Ukrainian).

Lakin, G.F. (1990). Biometrija. M.: Vysshaja shkola (in Russian). 